\title{
ANALISIS IMPLEMENTASI TALENT MANAGEMENT DALAM MENGEMBANGKAN KINERJA KARYAWAN YANG UNGGUL DAN BERBUDAYA
}

\author{
Putu Dharmawan Pradhana ${ }^{1}$, I Made Bima Devrasta Putra Astaki², I Dewa Ketut Gede \\ Prabawa $^{3}$ \\ ${ }^{1,2,3}$ Universitas Pendidikan Nasional Denpasar \\ Email: pradhana@undiknas.ac.id
}

\begin{abstract}
Abstrak
Sumber Daya Manusia (SDM) merupakan faktor penentu efektifitas kegiatan dalam organisasi. Keberhasilan dan kinerja seseorang dalam suatu bidang pekerjaan sangat ditentukan oleh tingkat kompetensi, kinerja profesional dan komitmen terhadap bidang pekerjaan yang digelutinya. Sumber daya manusia yang berkualitas akan memberikan pengaruh positif bagi organisasi/perusahaan, baik dari segi meningkatkan kinerja, efektivitas dan efisiensi dalam suatu perusahaan. Hal lain yang tidak kalah penting dan harus menjadi perhatian suatu organisasi/perusahaan adalah bagaimana mereka mengembangkan potensi sumber daya manusianya. Salah satu cara yang bisa dilakukan adalah melalui talent management. Talent management ini dapat diterapkan oleh berbagai institusi, baik instansi pemerintah, swasta maupun perusahaan lokal. Begitu juga dengan pegawai di Perusahaan Umum Daerah Air Minum Tirta Mangutama Kabupaten Badung. Pendekatan dalam penelitian ini adalah penelitian kualitatif. Sumber data yang digunakan terdiri dari data primer dan data sekunder. Teknik pengumpulan data dalam penelitian ini dengan cara observasi, wawancara, dan dokumentasi. Dalam menentukan informan digunakan teknik purposive sampling. Teknik pemeriksaan keabsahan data menggunakan teknik triangulasi sumber dan teknik triangulasi data, serta teknik analisis data menggunakan teknik Miles dan Huberman yaitu analisis model interaktif. Hasil yang diharapkan dalam penelitian ini adalah penerapan Talent Management dalam proses pengembangan kinerja pegawai yang unggul dan berbudaya pada Perusahaan Umum Daerah Air Minum Tirta Mangutama Kabupaten Badung.
\end{abstract}

Kata Kunci: Kinerja Karyawan, Manajemen Talenta, Budaya Organisasi.

\section{Abstract}

Human Resources $(H R)$ it is a determining factor for the effectiveness of activities within the organization. A person's success and performance in a field of work is largely determined by the level of competence, professional performance and commitment to the field of work he is engaged in. Quality human resources will have a positive effect on the organization/company, both in terms of improving performance, effectiveness and efficiency in a company. Another thing that is no less important and must be a concern for an organization/company is how they develop their human resource potential. One way that can be done is through talent management. This talent management can be applied by various institutions, both government agencies, private sector and local companies. Likewise, employees at the Regional Public Company for Drinking Water Tirta Mangutama, Badung Regency. The approach in this research is qualitative research. The data sources used consist of primary data and secondary data. Data collection techniques in this study by observation, interviews, and documentation. In determining the informants used purposive sampling technique. The technique of checking the validity of the data used the source triangulation technique and the triangulation technique, as well as the data analysis technique using the 
Miles and Huberman technique, namely interactive model analysis. The expected result in this research is the implementation of Talent Management in the process of developing superior and cultured employee performance at the Regional Public Company for Drinking Water Tirta Mangutama, Badung Regency.

Keywords: Employee performance, Talent Management, Organization Culture.

A. PENDAHULUAN

Sumber Daya Manusia (SDM) tinggi peranannya dalam memberi impek dalam tingkat efektivitas kegiatan organisasi. Tingginya kinerja seseorang diimbas dalam tingkat kompetensi, kinerja profesional berimpek dalam pekerjaan yang ditekuninya. Tingginya organisasi sejajar dalam sumber daya manusia yang mutlak. Menurut Ardana, dkk (2012) Sumber daya manusia berimpek dalam keberhasilan tingkat organisasi atau bisnis, sebab peran sumber daya manusia merupakan aset khusus perencanaan, pelaksanaan tingkat pengelolaan berbagai kegiatan suatu bisnis.

Kinerja karyawan menjadi perhatian utama bagi manajemen suatu perusahaan, karena kinerja karyawan akan berdampak pada kinerja organisasi. Suatu organisasi dapat terbentuk karena dipengaruhi oleh beberapa aspek seperti penyatuan visi dan misi serta tujuan yang sama yaitu tercapainya keberadaan sekelompok orang dalam suatu perusahaan. Menurut Siagian (dalam Ninla Elmawati Falabiba, 2019) organisasi adalah segala bentuk perkumpulan antara dua orang atau lebih yang bekerja sama dan terikat secara formal untuk mencapai suatu tujuan yang telah ditetapkan dalam suatu perkumpulan yang didalamnya terdapat beberapa orang yang disebut atasan dan sekelompok orang disebut bawahan. Model interaksi tersebut diselaraskan dengan aturan, norma keyakinan dan nilai tertentu yang ditetapkan oleh organisasi. Bentuk interaksi dari waktu ke waktu akan membentuk kebiasaan umum atau membentuk budaya organisasi.

Budaya Organisasi merupakan salah satu hal yang penting dalam jalannya suatu organisasi agar tujuan organisasi dapat tercapai sesuai dengan harapan yang diinginkan bersama. Dengan adanya penerapan budaya organisasi yang luas dapat memberikan pengaruh yang kuat terhadap struktur dan fungsional organisasi tersebut. Budaya organisasi yang kuat dapat mendukung tujuan-tujuan organisasi, namun sebaliknya jika budaya organisasi di suatu organisasi lemah atau negatif menghambat dan bertentangan dengan tujuan-tujuan organisasi.

Menurut Schein (2009), budaya organisasi adalah pola asumsi bersama yang dipelajari oleh suatu kelompok dalam memecahkan masalah melalui adaptasi eksternal dan integrasi internal, yang telah bekerja cukup baik untuk dipertimbangkan kebenarannya, oleh karena itu, untuk diajarkan kepada anggota baru sebagai cara yang benar untuk melihat, berpikir, dan merasakan kaitannya dengan masalahmasalah yang ada. Robbins (dalam Hasra Hartini, 2017) mengemukakan bahwa budaya organisasi adalah suatu persepsi bersama yang dianut oleh anggota-anggotanya atau suatu sistem dari makna bersama.

Hal yang tidak kalah penting dan harus diperhatikan oleh suatu organisasi/perusahaan adalah bagaimana organisasi/perusahaan tersebut mengembangkan potensi sumber daya manusianya. Pengembangan sumber daya manusia dapat dilakukan dengan mempertimbangkan potensi yang ada diantara karyawan, potensi ini harus ditemukan oleh perusahaan untuk dimanfaatkan dan di maksimalkan untuk mencapai tujuan perusahaan. Mengetahui potensi karyawan akan memudahkan suatu perusahaan untuk mengisi posisi atau jabatan yang ada, sesuai dengan keterampilan dan kemampuan karyawan tersebut. Salah satu cara untuk melakukan hal tersebut adalah melalui talent management (manajemen talenta).

Menurut penelitian dari (Anisah Anisah, 2020) manajemen talenta dapat digunakan sebagai strategi untuk mengembangkan kinerja karyawan. Sedangkan menurut (Theodora, 2015) dengan adanya manajemen talenta dalam suatu organisasi/perusahaan dapat 
mengembangkan kinerja karyawan. Pendapat lain mengatakan bahwa, menurut Walker (Windi et al., 2021) manajemen talenta merupakan proses sistematis yang dilakukan oleh perusahaan untuk menemukan, memilih, meningkatkan dan mempertahankan karyawan mereka yang paling berbakat untuk memenuhi kebutuhan perusahaan. Fatmasari (dalam Windi et al., 2021) Talenta tidak dapat diukur dan dipandang sebagai sesuatu yang di atas rata-rata, akan tetapi di ukur dengan istilah sesuai/cocok dengan harapan.

Dari definisi diatas dapat disimpulkan bahwa manajemen talenta merupakan serangkaian kegiatan yang meliputi pencarian sumber daya manusia yang bertalenta, menyeleksi talenta, mengembangkan talenta, serta mengelola atau mempertahankan talenta sesuai dengan kualifikasinya yang dibutuhkan dalam mencapai tujuan perusahaan. Adapun Indikator-indikator menurut (Hermen, 2018) yang bisa dijadikan sebagai ukuran, yaitu (1) Recruitment dan seleksi, (2) Perencanaan sukses, (3) Pelatihan dan pengembangan, (4) proses manajemen kinerja, (5) Kompensasi, (6) Retensi.

Manejemen talenta ini dapat diterapkan oleh berbagai lembaga, baik instansi pemerintah, swasta maupun perusahaan daerah. Begitu pula halnya pegawai di Perusahaan Umum Daerah (Perumda) Air Minum Tirta Mangutama Kabupaten Badung, dimana saat ini peneliti mengambil locus penelitian. Perumda Air Minum Tirta Mangutama Kabupaten Badung merupakan salah satu perusahaan daerah yang dimiliki oleh Pemerintah Kabupaten Badung (selain Perusahaan Daerah (PD) Pasar) yang berlokasi di Jl. Bedahulu No.3, Dauh Puri Kaja, Kecamatan Denpasar Utara, Kota Denpasar, Bali. Perumda Air Minum Tirta Mangutama Kabupaten Badung memiliki tugas untuk memberikan pelayanan, perawatan dan distribusi supply air bersih kepada masyarakat luas, khususnya di wilayah Kabupaten Badung.

Dari hasil wawancara awal dengan kepala personalia Perumda Air Minum Tirta Mangutama Kabupaten Badung, ada berbagai permasalahan yang pernah terjadi di Perumda Air Minum Tirta Mangutama Kabupaten Badung, seperti seringnya terjadi kebocoran jaringan pipa distribusi air, distribusi air macet/mati ke pelanggan, air keruh serta bau kaporit yang menyengat. Hal ini tentu saja berpotensi memberikan pengaruh buruk terhadap kepuasan pelanggan serta merusak image Perumda Air Minum Tirta Mangutama, bahkan Pemerintah Kabupaten Badung sebagai pemilik perusahaan daerah ini.

Permasalahan ini bisa terjadi karena berbagai faktor, baik faktor teknis maupun faktor lainnya. Salah satu faktor yang berperan dalam hal ini adalah faktor sumber daya manusia. Momok bagi suatu perusahaan adalah ketika sumber daya manusia atau pegawainya tidak seperti yang diharapkan, misalnya melakukan tindakan-tindakan indisipliner, seperti: terlambat masuk kerja, berkeliaran pada saat jam kerja atau bahkan mangkir dari pekerjaan. Kondisi ini seringkali dihadapi oleh suatu perusahaan, termasuk Perumda. Air Minum Tirta Mangutama Kabupaten Badung. Oleh karena begitu pentingnya faktor sumber daya manusia ini bagi suatu perusahaan, termasuk Perumda Air Minum Tirta Mangutama Kabupaten Badung. Dari berbagai permasalahan yang dihadapi Perumda Air Minum Tirta Mangutama Kabupaten Badung maka dalam hal ini dapat peneliti dapat mengambil kesimpulan bahwa proses perekrutan dan pengembangan pegawai di Perumda Air Minum Tirta Mangutama Kabupaten Badung belum optimal menerapkan standar sebagaimana seharusnya. Perekrutan dan pengembangan pegawai yang telah dilaksanakan ternyata kurang transparan dan banyak dipengaruhi oleh unsur politik, sehingga pegawai yang berhasil direkrut tidak memenuhi standar yang dibutuhkan perusahaan. Begitu pula halnya dengan pengembangan pengawai banyak dipengaruhi oleh unsur like and dislike dan kedekatan (nepotisme), yang pada akhirnya menurunkan kinerja pegawai. Berdasarkan hal tersebut peneliti bermaksud untuk ikut sumbang saran mengenai metode atau, cara yang dapat diterapkan oleh Perumda Air Minum Tirta Mangutama Kabupaten Badung agar memiliki pegawai yang berkinerja baik, yaitu melalui penerapan talent management (manajemen talenta). 
Dalam penelitian ini, peneliti menggunakan metode KUALITATIF, dalam hal ini peneliti ingin memahami proses dari implementasi talent management di Perusahaan umum daerah (Perumda) Air Minum Tirta Mangutama Kabupaten Badung. Tujuan penelitian ini adalah untuk mengetahui implementasi talent management dalam mengembangkan kinerja karyawan yang unggul dan berbudaya di Perumda Air Minum Tirta Mangutama Kabupaten Badung.

\section{B. METODE PENELITIAN}

Jenis penelitian ini menggunakan jenis penelitian Kualitatif. Adapun lokasi penelitian ini dilakukan di salah satu perusahaan daerah yang dimiliki pemerintah Kabupaten Badung yaitu Perusahaan umum daerah (Perumda) Tirta Mangutama Kabupaten Badung. Pusat pelayanan Perumda Air Minum Tirta Mangutama Kabupaten Badung terletak di Jl. Bedahulu No. 3, Dauh Puri Kaja, Kecamatan Denpasar Utara, Kota Denpasar, Bali yang beroperasi setiap hari Senin-Jumat dari pukul 07.30 hingga pukul 16.00. Alasan mengapa peneliti tertarik untuk melakukan penelitian di lokasi ini karena, peneliti menemukan suatu permasalahan atau fenomena, dimulai dari sistem perekrutan dan pengembangan pegawai yang telah dilaksanakan belum optimal hal ini dikarenakan sistem perekrutan yang dilakukan kurang transparan dan banyak dipengaruhi oleh unsur politik sehingga pegawai yang berhasil direkrut tidak memenuhi standar yang dibutuhkan perusahaan. Maka dari itu peneliti sangat tertarik untuk melakukan penelitian mengenai "Implementasi Talent Management dalam mengembangkan kinerja karyawaan yang unggul dan berbudaya" pada Perumda Tirta Mangutama Kabupaten Badung.

Dalam teknik pengumpulan data yang digunakan dalam penelitian adalah sebagai berikut, pertama Observasi, Wawancara dan Dokumentasi. Informan penelitian, Penentuan informan (narasumber) merupakan hal yang sangat penting untuk mendapatkan data yang akurat, sehingga penentuan informan harus dilakuan dengan cermat dan tepat. Informan yang digunakan untuk penelitian ini dipilih secara purposive sampling. Menurut Sugiyono (2018) Purposive sampling adalah teknik pengambilan sampel sumber data dengan pertimbangan tertentu. Oleh sebab itu, peneliti memutuskan informan yang paling sesuai dan tepat untuk menjadi narasumber yaitu: pertama, Kepala Personalia / Divisi Sumber Daya Manusia bagian dari Perumda Air Minum Tirta Mangutama Kabupaten Badung yang bertanggung jawab untuk mengelola sumber daya manusia (SDM) di perusahaan tersebut, meliputi perencanaan, seleksi/rekrutmen, pengembangan, manajemen kinerja, serta pembentukan budaya organisasi di perusahaan tersebut. Kedua Staff/Karyawan yang menjadi informan dalam penelitian ini adalah Costumer Service. Ketiga Staff/Karyawan yang bekerja terjun langsung ke lapangan dalam hal ini, team survey dan teknisi lapangan.

Selanjutnhya metode penelitian dalam penelitian ini, melakukan teknik pemeriksa keabsahan data dalam hal ini, merupakan sebuah proses untuk mengetahui kebenaran dari datadata yang diperoleh dari narasumber dilapangan. Menurut Sugiyono (2017) triangulasi dalam pengujian reliabilitas diartikan sebagai pengujian data dari berbagai sumber dengan cara yang berbeda dan pada waktu yang berbeda. Dengan demikian dalam penelitian ini menggunakan: Triangulasi Sumber Menurut Sugiyono (2017:350). Triangulasi Sumber untuk menguji krebilitas data dilakukan dengan cara mencetak data yang telah diperoleh melalui beberapa sumber. Berdasarkan penjelasan tersebut, dapat diketahui bahwa peneliti mempunyai informan yang diantaranya adalah: Kepala Personalia divisi Sumber daya manusia, Costumer Service, Staff/karyawan pengawas lapangan atau tim survey lapangan Perumda Air Minum Tirta Mangutama Kabupaten Badung. Hal ini dilakukan bertujuan untuk mencari tahu kebenaran di tempat penelitian. Tringulasi melalui sumber informan tersebut akan memberikan jawaban yang jelas tentang pertanyaan yang akan di berikan oleh peneliti. Selanjutnya peneliti menggunakan Tringulasi teknik dalam teknik kebasahan data. Menurut Sugiyono (2017:371) 
triangulasi teknik untuk menguji kredibilitas data dilakukan dengan cara mengecek data kepada sumber yang sama dengan teknik yang berbeda, berdasarkan pada penjelasan tersebut, peneliti melakukan teknik pengumpulan data, yang pertama melakukan Observasi, peneliti akan mengunjungi Perumda Tirta Mangutama Kabupaten Badung yang dipilih sebagai tempat penelitian yang kemudian akan mencari informasi untuk melengkapi data penelitian. Peneliti akan mengobservasi kondisi perusahaan daerah tersebut agar peneliti mendapatkan hasil fenomena secara langsung di tempat penelitian. Selanjutnya, peneliti akan melakukan wawancara dengan informan yang telah ditentukan dengan tujuan agar mendapatkan jawaban serta informasi yang dapat dikumpulkan. Terakhir, informasi dan data yang dicari oleh peneliti akan dikumpulkan melalui dokumentasi. Ketiga tahapan tersebut kemudian akan dijadikan sebagai sumber data dalam penelitian ini.

Teknik analisis data dalam penelitian kualitatif dilakukan sejak sebelum memasuki lapangan, selama di lapangan, dan setelah selesai dilapangan (Sugiono 2018). Analisis data menjadi pegangan bagi penelitian selanjutnya sampai teori yang grounded. Dapat disimpulkan bahwa proses mencari dan menyusun secara sistematis data-data yang diperoleh baik dari hasil observasi, wawancara, dan dokumentasi, dengan cara mengorganisasikan data ke dalam kategori, menjabarkan ke unit-unit, melakukan dan menyusun ke dalam pola, memilihi nama yang penting dan ada yang akan di pelajari dan membuat kesimpulan yang mudah di mengerti.

Menurut (Miles \& Huberman, 1994) mengemukakan bahwa aktivitas dalam analisis data kualitatif dilakukan secara interaktif dan berlangsung secara terus menerus sampai tuntas, sehingga datanya sudah jenuh. Aktivitas dalam analisis data, yaitu data collection, data reduction, data display, dan conclusion drawing/verification.

\section{HASIL DAN PEMBAHASAN}

Peneliti memaparkan beberapa aspek penting yang menjadi temuan dalam pengembangan kinerja karyawan melalui talent management di Perusahaan umum daerah (Perumda) Air Minum Tirta Mangutama Kabupaten Badung, serta akan terdapat pembahasan terhadap aspek temuan penelitian tersebut. Adapun metode yang peneliti gunakan dalam mengumpulkan data dalam temuan ini yaitu melalui observasi, wawancara serta dokumentasi. Dalam hal ini wawancara yang dilakukan dengan para informan yang telah ditentukan menggunakan teknik purposive sampling.

Sebelum menjelaskan proses temuan penelitian dan pembahasannya. Berkaitan dengan pengembangan kinerja karyawan di Perusahaan Umum Daerah (Perumda) Air Minum Tirta Mangutama Kabupaten Badung, maka diperlukannya strategi dan penerapan action (aksi) dalam menentukan seperti apa strategi yang digunakan agar Perumda Air Minum Tirta Mangutama Kabupaten Badung mampu menciptakan sumber daya manusia yang unggul dan berkualitas serta mampu memberikan pelayanan yang baik dan positif kepada masyarakat dan pelaku bisnis lainnya khususnya di wilayah Kabupaten Badung. Tentunya perusahaan daerah ini telah mempunyai strategi yang matang dalam upaya pengembangan kinerja karyawan yang unggul, di mulai dari recruitment sampai mendapatkan pelatihan dan pengembangan. Dalam penelitian ini peneliti berkesempatan untuk melakukan wawancara dengan beberapa informan dari Perumda Air Minum Tirta Mangutama Kabupaten Badung yaitu: Kepala personalia, Costumer Service, Staff/Karyawan pengawas lapangan/team Survey lapangan.

Berdasarkan beberapa temuan penelitian yang telah dipaparkan sebelumnya, maka dapat dipahami secara umum bahwa pengembangan kinerja karyawan di Perumda Air Minum Tirta Mangutama Kabupaten Badung terbilang begitu sederhana baik secara konsep dasar ataupu implementasinya. Adapun beberapa temuan penelitian berkaitan dengan pengembangan kinerja karyawan di Perumda Air Minum Tirta Mangutama Kabupaten Badung dapat terlihat dari beberapa aspek tertentu dalam pembahasan berikut ini: 


\begin{tabular}{|c|c|c|}
\hline No & Pembahasan & $\begin{array}{l}\text { Temuan Penelitian } \\
\end{array}$ \\
\hline 1. & $\begin{array}{l}\text { Pembahasan Metode } \\
\text { Pelatihan dan Pengembangan } \\
\text { Karyawan }\end{array}$ & $\begin{array}{l}\text { Dalam pengembangan karyawan melalui } \\
\text { Implementasi Talent Management, tentu peningkatan } \\
\text { kemampuan skill dari karyawan merupakan salah satu } \\
\text { aspek penting yang harus dilaksanakan oleh setiap } \\
\text { organisasi bisnis. Selain bermanfaat untuk setiap } \\
\text { SDM itu sendiri, hal ini tentunya akan memberi } \\
\text { dampak positif pula bagi kinerja yang ditunjukkan } \\
\text { sehingga operasional bisnis pun menjadi lebih } \\
\text { optimal untuk dijalankan. Dalam temuan penelitian, } \\
\text { peneliti dapat mengetahui salah satu penerapan Talent } \\
\text { Management yang dijalankan oleh Perumda Air } \\
\text { Minum Tirta Mangutama Kabupaten Badung yaitu } \\
\text { melalui pelaksanaan pelatihan dan pengembangan } \\
\text { kepada karyawan. Adapun beberapa tindakan } \\
\text { pelatihan dan pengembangan yang telah di lakukan di } \\
\text { Perumda sesuai dengan hasil wawancara dengan Ibu } \\
\text { I Gusti Ayu Emas Trisnadewi selaku Kepala } \\
\text { Personalia, seperti dilatih secara langsung oleh } \\
\text { pimpinan bisnis dalam hal ini direktur langsung, di } \\
\text { tempat kerja sesuai dengan bidang kerja yng } \\
\text { dijalankan, dikirim ke dalam beberapa event atau } \\
\text { coaching class tertentu diluar dari bisnis tersebut, } \\
\text { serta melakukan beberapa pelatihan dan } \\
\text { pengembangan secara mandiri bersama dengan } \\
\text { beberapa rekan kerja dari karyawan di bidang lain } \\
\text { untuk menambah kemampuan tertentu. } \\
\text { Berdasarkan temuan penelian dan penelitian } \\
\text { terdahulu yang telah dipaparkan tersebut, peneliti } \\
\text { berpendapat bahwa penerapan metode pelatihan dan } \\
\text { pengembangan pada karyawan Perumda Air Minum } \\
\text { Tirta Mangutama Kabupaten Badung selain } \\
\text { menggunakan metode pendekatan talent } \\
\text { management, ternyata juga menerapkan metode on } \\
\text { the job ataupun off the job training. Metode melalui } \\
\text { pendekatan pelatihan terbilang tepat karena dalam } \\
\text { prakteknya, Perumda Air Minum Tirta Mangutama } \\
\text { Kabupaten Badung merupakan perusahaan daerah } \\
\text { yang bergerak dibidang pelayanan dan merupakan } \\
\text { penyedia air bersih ke masyarakat dan pelaku bisnis, } \\
\text { tentu dalam hal ini metode on the job dan off the job } \\
\text { training tepat untuk digunakan, sehingga tentunya } \\
\text { dengan harapan agar setiap karyawan mampu untuk } \\
\text { meningkatkan skill yang dimiliki sesuai dengan } \\
\text { bidang pekerjaannya ataupun justru dapat menambah } \\
\text { kemampuan di bidang kerja yang lainnya. }\end{array}$ \\
\hline 2. & $\begin{array}{l}\text { Pembahasan Penerapan } \\
\text { Budaya Organisasi }\end{array}$ & $\begin{array}{l}\text { Dalam wawancara sebelumnya dengan informan, } \\
\text { peneliti menemukan sesuatu hal yang menarik di } \\
\text { lokasi penelitian, yaitu penerapan budaya organisasi } \\
\text { di Perumda Air Minum Tirta Mangutama Kabupaten }\end{array}$ \\
\hline
\end{tabular}




\begin{tabular}{|c|c|c|}
\hline & & $\begin{array}{l}\text { Badung, dimana perusahaan daerah tersebut memiliki } \\
\text { organisasi yang bernama Dharma Wanita, yang } \\
\text { beranggotakan seluruh karyawan wanita serta para } \\
\text { istri dari pejabat dan pegawai. Tujuan dibentuknya } \\
\text { organisasi ini yaitu untuk mempererat tali } \\
\text { silahturahmi dan memupuk rasa kebersamaan di } \\
\text { antara keluarga besar pegawai. Peneliti menemukan } \\
\text { hal menarik disini, dimana organisasi ini memberikan } \\
\text { dampak positif dan membuktikan bahwa wanita } \\
\text { mampu dalam memberi perubahan. } \\
\text { Dengan adanya organisasi Dharma Wanita di } \\
\text { Perumda. Air Minum Tirta Mangutama Kabupaten } \\
\text { Badung. Hal ini membuktian bahwa budaya } \\
\text { organisasi sudah diaplikasikan di perusahaan ini. Itu } \\
\text { artinya, perusahaan ini menyadari betul akan } \\
\text { pentingnya suatu organisasi binaan dalam } \\
\text { mendukung pencapaian tujuan perusahaan. } \\
\text { Organisasi binaan ini (Dharma Wanita) bisa menjadi } \\
\text { partner perusahaan untuk urusan non teknis, seperti } \\
\text { urusan sosial kemasyarakatan. Sinergitas antara } \\
\text { perusahaan dengan organisasi Dharma Wanita ini } \\
\text { akan meningkatkan soliditas dan kerativitas } \\
\text { perusahaan. } \\
\text { Hal ini juga sejalan dengan teori dari Susanto (1997) } \\
\text { bahwa culture perusahaan dapat dimanfaatkan } \\
\text { menjadi andalan organisasi dalam menerima } \\
\text { tantangan dan perubahan. Intinya, tidak semua hal } \\
\text { dapat ditangani sendiri oleh perusahaan. Perusahaan } \\
\text { juga membutuhkan bantuan dari pihak lain. } \\
\text { Organisasi-organisasi inilah yg dapat membantu } \\
\text { perusahaan untuk menangani hal-hal khusus atau non } \\
\text { teknis lainnya. Perumda Air Minum Tirta Mangutama } \\
\text { Kabupaten Badung, sudah mengaplikasikan hal } \\
\text { tersebut, melalui budaya organisasi yg baik dan } \\
\text { terprogram. }\end{array}$ \\
\hline 3. & $\begin{array}{lr}\text { Pembahasan } & \text { Service } \\
\text { Karyawan Kepada Pelanggan }\end{array}$ & $\begin{array}{l}\text { Hasil penelitian dari temuan yang telah dipaparkan, } \\
\text { peneliti mengetahui bahwa terdapat salah satu aspek } \\
\text { dalam ruang lingkup pengembangan kinerja } \\
\text { karyawan melalui Talent Managemet, yang menjadi } \\
\text { daya tarik atau faktor penting dibalik Perumda Air } \\
\text { Minum Tirta Mangutama Kabupaten Badung } \\
\text { mendapat kepercayaan dari masyarakat yaitu karena } \\
\text { berbagai aspek, salah satunya yaitu aspek pelayanan } \\
\text { (service) dari para karyawan yang bekerja di } \\
\text { dalamnya. } \\
\text { Beberapa poin catatan penting yang disampaikan oleh } \\
\text { informan Perumda Air Minum Tirta Mangutama } \\
\text { Kabupaten Badung, yaitu selalu mengingatkan dan } \\
\text { menekankan pada setiap karyawan yang ada untuk } \\
\text { membangun komunikasi (komunikatif) dengan baik }\end{array}$ \\
\hline
\end{tabular}




\begin{tabular}{|l|l|}
\hline & $\begin{array}{l}\text { kepada pelanggan (customer), bersikap yang ramah, } \\
\text { serta meningkatkan kualitas diri agar emosi lebih } \\
\text { terjaga saat berhadapan langsung dengan pelanggan. } \\
\text { Menurut pendapat peneliti, berdasarkan proses } \\
\text { pengembangan kinerja yang dilakukan dalam aspek } \\
\text { Service melalui system komunikasi interpersonal } \\
\text { tersebut, Perumda Air Minum Tirta Mangutama } \\
\text { Kabupaten Badung terbilang cukup berhasil dalam } \\
\text { mengimplementasikannya, ini terbukti dari dulu } \\
\text { hingga sekarang Perumda Air Minum Tirta } \\
\text { Mangutama Kabupaten Badung masih aktif serta } \\
\text { mampu memberikan yang terbaik kepada para pelaku } \\
\text { bisnis selain itu juga dikarenakan pelatihan yang } \\
\text { didapatkan salah satunya yaitu mengenai pelatihan } \\
\text { komunikasi yang baik, dan juga Perumda Air Minum } \\
\text { Tirta Mangutama Kabupaten Badung memiliki } \\
\text { Standar Operasional Pegawai (SOP) dalam } \\
\text { menangani Pelanggan. }\end{array}$ \\
\hline
\end{tabular}

\section{KESIMPULAN}

Proses perekrutan dan pengembangan kemampuan karyawan Perumda Air Minum Tirta Mangutama Kabupaten Badung terbilang begitu sederhana, baik secara konsep dasar maupun implementasinya. Dimulai dari sistem perekrutan karyawan hingga mendapatkan pendidikan dan pelatihan untuk mengembangkan kinerja karyawan di Perumda terbilang sederhana dan konsisten untuk dilakukan. Pelatihan dan pengembangan karyawan di Perumda Air Minum Tirta Mangutama Kabupaten Badung, selain mengimplementasikan Talent Management dalam proses pengembangan talenta karyawan, ternyata perusahaan daerah ini mempunyai metode lain dalam mengembangkan kinerja karyawan, yaitu metode pelatihan non-formal dan formal serta disesuaikan dengan kebutuhan pendekatan on the job training ataupun off the job training kepada setiap karyawan sesuai dengan bidang kerjanya.

Penerapan budaya organisasi yang diterapkan di Perumda Air Minum Tirta Mangutama Kabupaten Badung mampu memberikan dampak yang positif bagi jalannya suatu organisasi hal ini dibuktikan adanya budaya organisasi yang dijalankan di Perumda adalah organisasi Dharma Wanita, organisasi yang beranggotakan para karyawan wanita, mampu membuktikan organisasi ini memberi dampak yang positif bagi kemajuan dan kekompakan karyawan Perumda, hal ini juga dibuktikan dengan tujuan dan program-program yang dijalankan oleh Organisasi Dharma Wanita.

Dalam aspek pelayanan yang dimana Perumda Air Minum Tirta Mangutama Kabupaten Badung dalam hal menangani keluhan pelanggan Perumda Air Minum Tirta Mangutama Kabupaten Badung memiliki Web resmi yang bernama Sistem Informasi Layanan Konsumen (SILK), didalam web tersebut berisikan form pengaduan masyarakat mengenai pelayanan dan produk Perumda Kabupaten Badung. Dalam hal menangani complain/keluahan pelanggan Perumda Air Minum Tirta Mangutama Kabupaten Badung mempunyai SOP (Standar Operasional Prosedur) khusus dalam hal itu.

Faktor penting dalam pelayanan di Perumda Air Minum Tirta Mangutama Kabupaten Badung untuk dapat mempertahankan kepercayaan pelanggan dan pelaku bisnis lainnya, yaitu dengan selalu mengutamakan pelayanan melalui komunikasi interpersonal oleh karyawan kepada pelanggan. 


\section{REFERENSI}

Aisyah, E. N. (1998). Analisis Information System, Strategic Analysis and Evaluation Sebagai Alat Ukur Kinerja Perusahaan. 263-272.

Anisah Anisah, S. A. (2020). Konsep Manajemen Talenta dan Pengaruhnya Terhadap Kinerja Karyawan. Jurnal Manajemen Dan Sains, Vol 5, No.

Ardiansyah, Y., \& Sulistiyowati, L. H. (2018). Pengaruh Kompetensi dan Kecerdasan Emosional Terhadap Kinerja Pegawai. Jurnal Inspirasi Bisnis dan Manajemen, 2(1), 91. https://doi.org/10.33603/jibm.v2i1.1064

Basyit, A., Sutikno, B., \& Dwiharto, J. (2020). Pengaruh Tingkat Pendidikan Dan Pengalaman Kerja Terhadap Kinerja Karyawan. Jurnal EMA, 5(1), 60-67. https://doi.org/10.47335/ema.v5i1.44

Hasra Hartina. (2017). нской организации по разделу «Эпидемиологическая безопасностьNo Title. Manajemen Asuhan Kebidanan Pada Bayi Dengan Caput Succedaneum di RSUD Syekh Yusuf Gowa Tahun, 4, 9-15.

Hermen. (2018). Analisis Talent Management dan Motivasi Kerja Terhadap Kinerja Karyawan. Vol.7/No.3.

Hidayat, T. (2012). Pengaruh Lingkungan Kerja dan Disiplin Kerja serta Motivasi Kerja Terhadap Kinerja Karyawan Perusahaan Daerah Air Minum (PDAM) Kabupaten Lumajang. Jurnal Penelitian Ilmu Ekonomi, Vol. 2 No.

Krissetyanti, E. P. L. (2013). Penerapan Strategi Manajemen Talenta Dalam Pengembangan PNS. Jurnal Kebijakan dan Manajemen PNS, 7(1), 1-15.

Miles, \& Huberman. (1994). Qualitative Data Analysis: An Expanded Sourcebook (berilustra). SAGE..

Pella, \& Inayati. (2011). Talent Management Mengembangkan SDM Untuk Mencapai Pertumbuhan dan Kinerja Prima (S. Rizaldi (ed.)). PT Gramedia Pustaka Utama.

Purhantara, W. (2010). Penataan Ulang Organisasi Dengan Modern Quality Management. Informasi, 36(1), 56-71. https://doi.org/10.21831/informasi.v1i1.5664

Rismawati, M. (2018). Evaluasi Kinerja Penilaian Kinerja Atas Dasar Prestasi Kerja Berorientasi Kedepan (M. Ismail (ed.)). Celebas Media Perkasa, 2018.

Riyadi, S. (2011). Pengaruh Kompensasi Finansial, Gaya Kepemimpinan, dan Motivasi Kerja Terhadap Kinerja Karyawan pada Perusahaan Manufaktur di Jawa Timur. Jurnal Manajemen Dan Kewirausahaan, 13(1). https://doi.org/10.9744/jmk.13.1.4045

Soetrisno, A. P., \& Gilang, A. (2018). Pengaruh Kompetensi terhadap Kinerja Karyawan (Studi di PT. Telekomunikasi Indonesia Tbk Witel Bandung). JURISMA : Jurnal Riset Bisnis \& Manajemen, 8(1). https://doi.org/10.34010/jurisma.v8i1.998

Sulaksono, H. (2015). Budaya Organisasi dan Kinerja. In Google Book (p. 143). https://books.google.co.id/books?id=kDiRDwAAQBAJ\&printsec=frontcover\&dq=pe ngertian+kinerja\&hl=id\&sa=X\&ved=0ahUKEwjc1NP22_ToAhUEheYKHSGcAccQ 6AEIMDAB\# $\mathrm{v}=$ onepage $\& \mathrm{q} \& \mathrm{f}=$ false

Susanto. (2018). Sistem Pengambilan Keputusan Penilaian Indek Kinerja Karyawan Dinas Pendapatan Kabupaten Pringsewu Dengan Pendekatan Weighted Product. Jurnal Teknologi Komputer dan Sistem Informasi, Vol 1.

Sutrisno. (2019). Budaya Organisasi. Prenada Media.

Theodora, O. (2015). Pengaruh motivasi kerja terhadap kinerja karyawan PT. Sejahtera Motor Gemilang. Agora, 3(2), 187-195.

Tuala, R. P. (2020). Budaya Organisasi dan Kepemimpinan di Lembaga Pendidikan Islam. In Encephale (Vol. 53, Issue 1). http://dx.doi.org/10.1016/j.encep.2012.03.001 
Vidianingtyas, R. N., \& Putri, W. H. (2014). Pengaruh kompensasi, kepuasan kerja, motivasi kerja dan gaya kepemimpinan terhadap kinerja karyawan pada perusahaan jasa katering di daerah istimewa yogyakarta. Efektif Jurnal Bisnis Dan Ekonomi, 5(1), 99110.

Windi, W. N., Windi, W. N., Ahman, E., Santoso, B., Studi, P., \& Manajemen, M. (2021). Analisis Talent Management dan Motivasi Kerja. 7(3), 11-17.

Windi1, W. N., Ahman2, E., \& Santoso3, B. (2021). analisis talent management dan motivasi kerja terhadap kinerja karyawan. Jurnal Investasi, 7(3). 